Provided for non-commercial research and education use. Not for reproduction, distribution or commercial use.

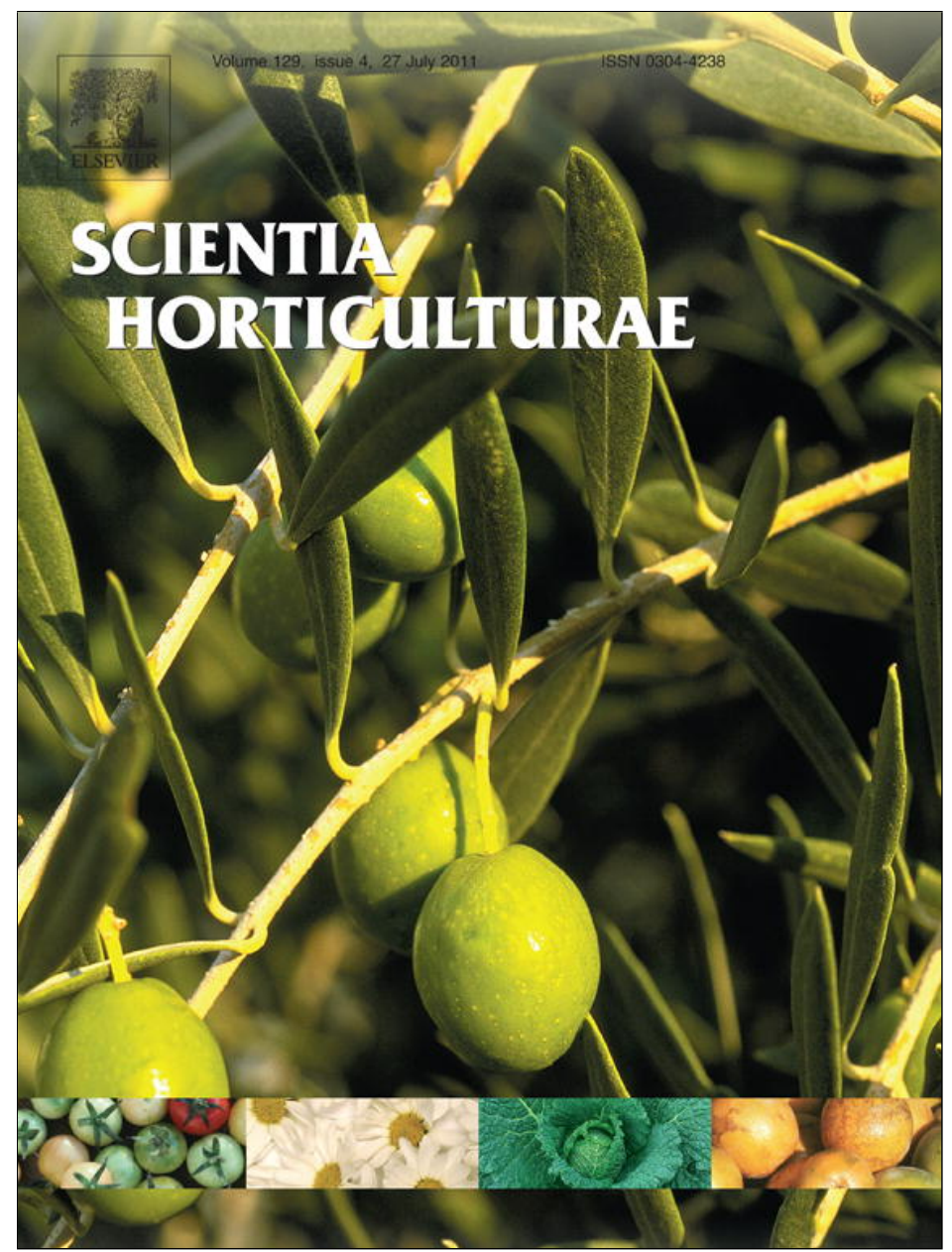

This article appeared in a journal published by Elsevier. The attached copy is furnished to the author for internal non-commercial research and education use, including for instruction at the authors institution and sharing with colleagues.

Other uses, including reproduction and distribution, or selling or licensing copies, or posting to personal, institutional or third party websites are prohibited.

In most cases authors are permitted to post their version of the article (e.g. in Word or Tex form) to their personal website or institutional repository. Authors requiring further information regarding Elsevier's archiving and manuscript policies are encouraged to visit:

http://www.elsevier.com/copyright 


\title{
Cost-efficient light control for production of two campanula species
}

\author{
Katrine Heinsvig Kjaer ${ }^{\mathrm{a}, *}$, Carl-Otto Ottosen ${ }^{\mathrm{a}}$, Bo Nørregaard Jørgensen ${ }^{\mathrm{b}}$ \\ a Department of Horticulture Aarhus University, Kirstinebjergvej 10, 5792 Aarslev, Denmark \\ b The Maersk Mc-Kinney Møller Institute University of Southern Denmark, Campusvej 55, 5230 Odense M, Denmark
}

\section{A R T I C L E I N F O}

\section{Article history:}

Received 25 February 2011

Received in revised form 2 May 2011

Accepted 5 May 2011

\section{Keywords:}

Flowering

Phytochrome

Supplemental light

Electricity costs

LD plants

Climate control

\begin{abstract}
A B S T R A C T
A cost-efficient light control system based on weather forecasts, electricity prices and daily photosynthesis integral (DPI) was evaluated for application in the commercial production of the long-day (LD) plant Campanula portenschlagiana ‘Blue Get Mee' and C. cochlearifolia 'Blue Wonder'. Experiments were conducted under both autumn and spring conditions and included four treatments. Three treatments were controlled by the software system DynaLight Desktop which automatically defined the most costefficient use of supplemental light, -based on a predefined set point of DPI, forecasted solar irradiance and the market price on electricity. The set points of DPI in the three treatments were 300,450 and $600 \mathrm{mmol}$ $\mathrm{CO}_{2} \mathrm{~m}^{-2}$ leaf $\mathrm{d}^{-1}$ and the treatments were compared with a traditional LD 19-h treatment. The DPI-based light control strategy resulted in very irregular light patterns including daily periods of solar irradiance combined with supplemental light in low light periods and a night period interrupted by irregular light breaks (NB-lighting). Both campanula species flowered in the DPI-based treatments during spring, but the flowering percentage was low and non-uniform during autumn. This was caused by a combination of the irregular light, low natural light intensities and a decrease in daily light integral (DLI), and could be restored by maintaining a continuous $19 \mathrm{~h}$ photoperiod with incandescent lamps $\left(<5 \mu \mathrm{mol} \mathrm{m}^{-2} \mathrm{~s}^{-1}\right)$, illustrating that photoperiod was an important factor for flowering in LD species grown under low light intensities. Growth in terms of carbon gain was marginally affected by the irregular light and a $25 \%$ reduction in electricity costs was achieved without major reductions in plant quality in spring. Our results illustrate that plant production of LD species can be maintained in a cost-efficient light control system where the use of supplemental light is based on weather forecasts and electricity prices.
\end{abstract}

(C) 2011 Elsevier B.V. All rights reserved.

\section{Introduction}

Protected plant production systems in the northern hemisphere increasingly rely on the addition of supplemental light both to extend the day length and to increase the daily light integral (DLI). However, as electricity prices vary on an hourly basis, the sustainable and optimal use of supplemental light is highly linked to the use and cost of electricity. In a recent developed light control system the timing and use of supplemental light is based on weather forecasts and electricity prices and controlled by predefined set points for daily photosynthesis integral (DPI) (Markvart et al., 2009; Kjaer and Ottosen, 2011). This means that the daily light hours will not occur continuously, but instead divided into periods of solar irradiance combined with supplemental light in low light periods during the day, and a night period interrupted by irregular light breaks

Abbreviations: DLD, Daily Light duration; DPI, Daily photosynthesis integral; NB, Night break.

* Corresponding author. Tel.: +45 8999 3315; fax: +45 89993490.

E-mail address: katrine.kjaer@agrsci.dk (K.H. Kjaer).
(NB lighting). Furthermore, the length of the NB lighting periods is based on set points for DPI and forecasted solar irradiance.

Campanula portenschlagiana 'Blue Get Mee' and C. cochlearifolia 'Blue Wonder' are long-day (LD) plants and recommended greenhouse production conditions for different campanula species include a minimum photoperiod of $14 \mathrm{~h}$ (Moe and Heide, 1985). However, rapid and uniform flowering can also be achieved when campanula and various other species of LD plants are illuminated with incandescent light $\left(2-5 \mu \mathrm{mol} \mathrm{m}^{-2} \mathrm{~s}^{-1}\right)$ for $4 \mathrm{~h}$ of NB lighting in the middle of a $12 \mathrm{~h}$ night (e.g. $2200-0200 \mathrm{~h}$ ) or continuous light is provided by incandescent lamps during the entire night (Moe et al., 1991; Runkle et al., 1998). If the periods of NB lighting are shorter than $4 \mathrm{~h}$, flowering may become non-uniform and delayed in some species (Runkle et al., 1998), and if the periods are longer than $4 \mathrm{~h}$, the number of flowers may not increase further (Albrecht and Lehmann, 1991; Hamaker et al., 1996). Cyclic lighting, in which lamps are turned on and off during the $4 \mathrm{~h}$ of NB lighting in the middle of the night provide advantages in the form of energy savings, but flowering in some LD species may be incomplete, delayed or non-uniform compared to plants grown under continuous incandescent light (Bickford and Dunn, 1972; Blanchard and Runkle, 2010). 
Our alternative approach is based on controlling the timing and use of supplemental light in relation to hourly changes in electricity prices and forecasted solar irradiance in combination with predefined DPI's. The advantage of this approach is energy saving in high-cost periods during the day due to reduced use of supplemental light, but the occurrence of shorter day (SD) may delay flowering or provide incomplete and non-uniform flowering due to a highly unpredictable light pattern. Plants have a circadian rhythm based on light-regulated processes (Dodd et al., 2005; Resco et al., 2009). Our hypothesis is that the irregular changes in the distribution and duration of the light periods will disturb the circadian rhythm. However, these disturbances will not affect overall plant dry matter production as recently reported for the SD plant chrysanthemum (Kjaer and Ottosen, 2011). Furthermore, several different strategies of NB lighting have not delayed flowering in campanula (Moe et al., 1991; Runkle et al., 1998; Blanchard and Runkle, 2010), suggesting that the development of induced flowers in this species and other LD plants depend more on the duration of light than on the distribution of light during the day. The aim of the present study was to evaluate whether the occurrence of SD and a highly unpredictable light pattern had any negative effect on growth and development on campanula LD plants.

\section{Material and methods}

\subsection{Plant material and growth conditions}

600 plantlets of $C$. portenschlagiana 'Blue Get Mee' and $C$. cochlearifolia 'Blue Wonder' were received from a commercial grower (PKM A/S, Odense, Denmark) in $10.5 \mathrm{~cm}$ pots. Plants were fertigated by flooding every second day with nutrient solution consisting of $5.7 \mathrm{mM} \mathrm{NaNO}_{3}, 12.6 \mathrm{mM} \mathrm{NH}_{4} \mathrm{NO}_{3}, 8.9 \mathrm{mM} \mathrm{KCl}, 0.7 \mathrm{mM}$ Fe-EDTA, $47.6 \mathrm{mM} \mathrm{KNO}_{3}, 0.4 \mathrm{mM}\left(\mathrm{NH}_{4}\right)_{2} \mathrm{SO}_{4}, 3.4 \mathrm{mM}\left(\mathrm{NH}_{4}\right) \mathrm{H}_{2} \mathrm{PO}_{4}$, $2.6 \mathrm{mM} \mathrm{KH}_{2} \mathrm{PO}_{4}, 5.8 \mathrm{mM} \mathrm{MgSO}_{4}$ and micronutrients.

The experiment was carried out from 9 October to 18 December 2009 and repeated from 12 January to 26 March 2010 in a greenhouse located at the Department of Horticulture, University of Aarhus (Aarslev, Denmark, Lat $55^{\circ} \mathrm{N}$ ). During this period, the natural day length decreases from $11 \mathrm{~h}$ in early October to $7 \mathrm{~h}$ in mid December, and increases from $7.5 \mathrm{~h}$ to $12.5 \mathrm{~h}$ from January to late march. The experiment was performed in two compartments each $9.9 \times 7.6 \mathrm{~m}$ which were subdivided in two units to allow for a total of four treatments with different light settings. The set point for $\mathrm{CO}_{2}$ was $700 \mu \mathrm{ll}^{-1}$ during the light periods (day or supplemental light), the night temperature was $15^{\circ} \mathrm{C}$ and the average day temperature was $18^{\circ} \mathrm{C}$. Supplemental light provided $\approx 60 \mu \mathrm{mol} \mathrm{m}^{-2} \mathrm{~s}^{-1}$ at table level by high-pressure sodium lamps (SON-T agro, $600 \mathrm{~W}$, Philips, Eindhoven, The Netherlands).

The supplemental light control strategy was the same in all treatments and based on a leaf photosynthesis model that calculated optimum photosynthesis at a given light intensity as a function of leaf temperature and $\mathrm{CO}_{2}$ concentration (Aaslyng et al., 2003). The set points were adjusted every $10 \mathrm{~min}$ based on actual irradiance and temperature, in an attempt to optimize the $\mathrm{CO}_{2}$ level based on the leaf photosynthesis model, with the overall aim of reaching $80 \%$ of the optimum photosynthesis. In the LD treatment, the continuous 19-h light period was maintained from $2200 \mathrm{~h}$ to $1700 \mathrm{~h}$ by turning on the supplemental light when the photosynthetic photon flux density (PPF) was below $198 \mu \mathrm{mol} \mathrm{m}^{-2} \mathrm{~s}^{-1}$. In the three other treatments the timing and use of supplemental light was controlled by 24 -h forecasted solar irradiance and hourly changes in electricity prices during the hours from $2000 \mathrm{~h}$ to $1700 \mathrm{~h}$ by the software package developed in connection with the project (DynaLight Desktop, University of Southern Denmark, Odense, Denmark).

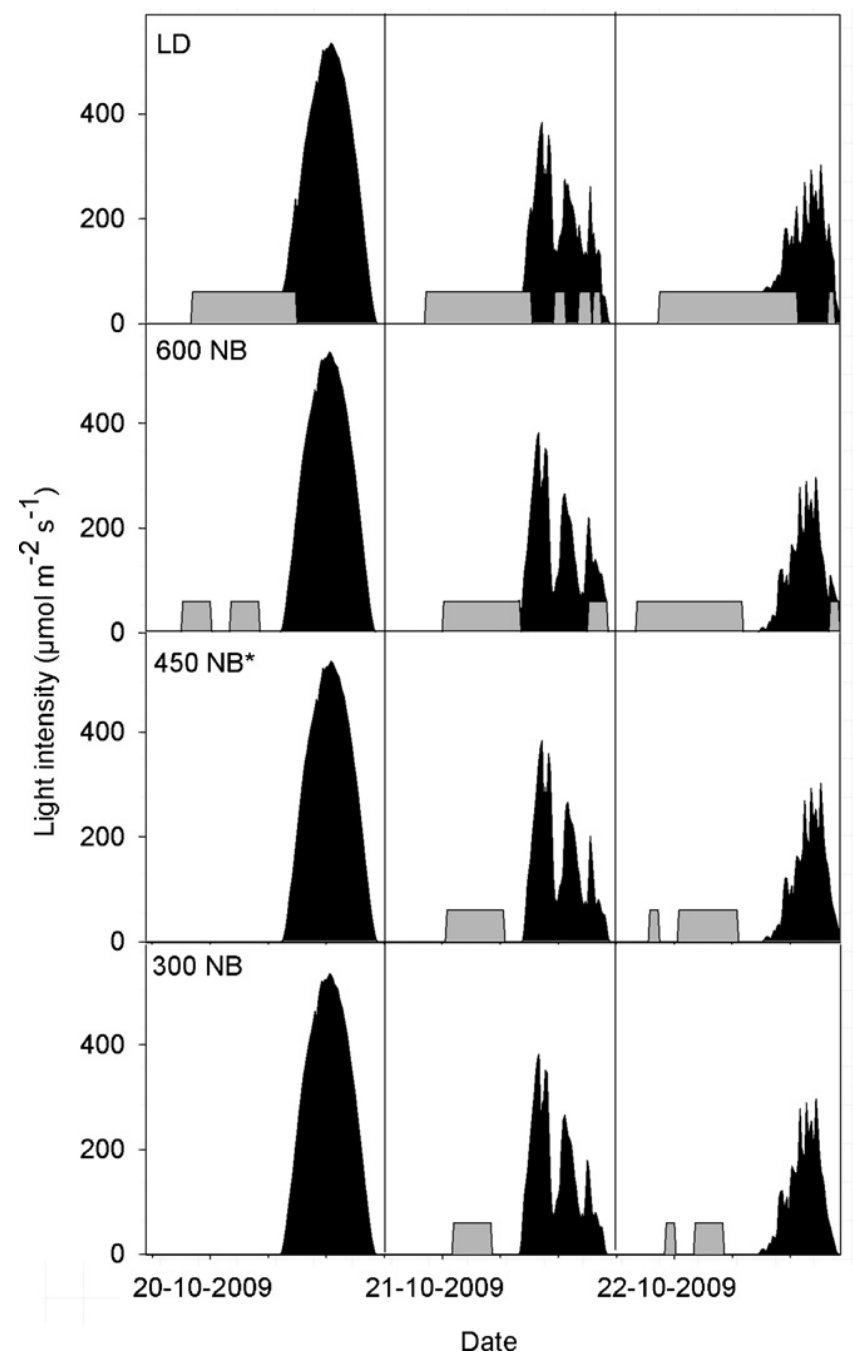

Fig. 1. An example of daily light duration (DLD) and light intensities $\left(\mu \mathrm{mol} \mathrm{m}^{-2} \mathrm{~s}^{-1}\right)$ of solar irradiation (dark areas) and supplemental light (grey areas) in four greenhouse treatments with different light control strategies. The treatments were long day (LD) with a day length of $\approx 19 \mathrm{~h}, 600 \mathrm{NB}$ with a set point for daily photosynthesis integral (DPI) of $600 \mathrm{mmol} \mathrm{CO}_{2} \mathrm{~m}^{-2}$ leaf s $\mathrm{s}^{-1}, 450 \mathrm{NB}^{*}$ (DPI $\approx 450 \mathrm{mmol} \mathrm{CO}_{2} \mathrm{~m}^{-2}$ leaf $\left.\mathrm{s}^{-1}\right)$ and including $\approx 19 \mathrm{~h}$ incandescent light $\left(<5 \mu \mathrm{mol} \mathrm{m}^{-2} \mathrm{~s}^{-1}\right)$, and $300 \mathrm{NB}$ (DPI $\approx 300 \mathrm{mmol} \mathrm{CO}_{2} \mathrm{~m}^{-2}$ leaf s${ }^{-1}$ ). NB refers to irregular night breaks of light.

At the beginning of the experiment, a set point for the daily photosynthesis integral (DPI) was defined for each treatment in the DynaLight program. For the three treatments, the DPI's were 300 , 450 and $600 \mathrm{mmol} \mathrm{CO}_{2} \mathrm{~m}^{-2}$ leaf $\mathrm{d}^{-1}$. Every day at $1900 \mathrm{~h}$, the supplemental light settings for the subsequent $24 \mathrm{~h}$ was calculated in three steps for each of the three treatments: (1) The expected DPI was calculated based on the forecasted solar irradiance obtained from the Danish Metrological Institute (DMI, 2011), (2) if the set point for DPI was not reached by solar irradiance, the software calculated the most price-efficient timing of using supplemental light based on the electricity costs obtained from NordPool (Nord Pool Spot, 2011), (3) DynaLight then automatically transferred the resulting set points for timing and use of supplemental light to the climate computer (LCC Completa Senmatic, Søndersø, Denmark) and defined the light periods during the subsequent $24 \mathrm{~h}$. The three treatments were named $300 \mathrm{NB}, 450 \mathrm{NB}^{*}$ and $600 \mathrm{NB}$ where NB refers to night breaks of light and the * refers to an additional light setting of continuous lighting with $<5 \mu \mathrm{mol} \mathrm{m}^{-2} \mathrm{~s}^{-1}$ at plant level from $2200 \mathrm{~h}$ to $1700 \mathrm{~h}$ by four incandescent lamps. An example of how the light periods were distributed in the four treatments during a three day period in autumn is shown in Fig. 1. 


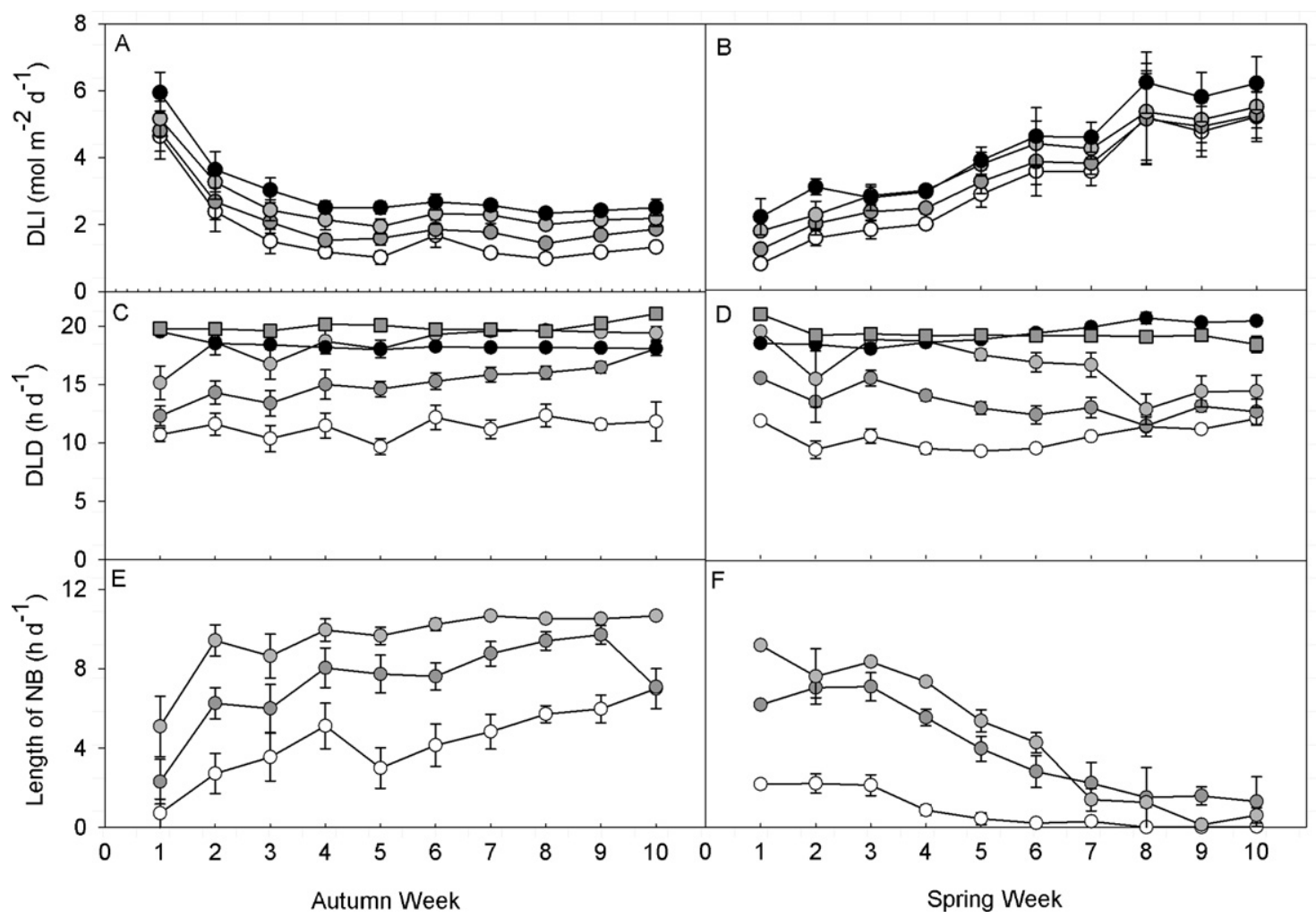

Fig. 2. (A and B) Daily light integral (DLI), (C and D) daily light duration (DLD) and (E and F) length of night breaks (NB) in autumn (A, C, D) and spring conditions (B, D, F). Average values per week $( \pm \mathrm{SE})$ are shown for four greenhouse treatments with different light control strategies, and repeated for one of the treatments including $\approx 19 \mathrm{~h}$ of incandescent light. Treatments were long day (LD) with a day length of $\approx 19 \mathrm{~h}$ (black circles), $600 \mathrm{NB}$ with a set point for daily photosynthesis integral (DPI) of $600 \mathrm{mmol} \mathrm{CO} 2$ $\mathrm{m}^{-2}$ leaf s ${ }^{-1}$ (light grey circles), $450 \mathrm{NB}^{*}\left(\mathrm{DPI} \approx 450 \mathrm{mmol} \mathrm{CO}_{2} \mathrm{~m}^{-2}\right.$ leaf s $\mathrm{s}^{-1}$ ) (dark grey circles) and including $\approx 19 \mathrm{~h}$ incandescent light $\left(<5 \mu \mathrm{mol} \mathrm{m}^{-2} \mathrm{~s}^{-1}\right.$ ), (dark grey squares), and $300 \mathrm{NB}$ with $\mathrm{DPI} \approx 300 \mathrm{mmol} \mathrm{CO}_{2} \mathrm{~m}^{-2}$ leaf $^{-1}$ (white circles). NB refers to irregular night breaks of light.

Inside the greenhouse, light intensity (PFD), air temperature, relative humidity $(\mathrm{RH})$ and $\mathrm{CO}_{2}$ concentrations were recorded in each treatment at table level. Additionally, the state of supplemental light (on or off) was recorded. The PPF was recorded at a weather station above the greenhouse, and the light transmission factor of the greenhouse (0.5) was used to calculate the light intensity inside the greenhouse. The daily light integrals (DLI) from supplemental light and natural PPF were summed. Daily light duration (DLD) was calculated as the number of hours of solar irradiation during the day plus the total number of hours the supplemental light was turned on during the night (length of NB). For the $450 \mathrm{NB}^{*}$ treatment the calculations of DLD were both including and excluding the additional hours of incandescent light (Fig. 2).

\subsection{Plant growth and physiology}

During the autumn experiment, six plants of each campanula cultivar were harvested prior to the start of the experiment (9 October 2009). Eight plants of each cultivar were harvested both after 24 days (11 November 2009) and at the end of production; 'Blue Get Mee' after 70 days (14 December 2009) and 'Blue Wonder' after 74 days (18 December 2009). During the spring experiments the same procedure was followed with a harvest prior to start of experiment (12 January 2010), after 24 days ( 5 February 2010) and at the end of production; 'Blue Get Mee' and 'Blue Wonder' after 70 days (26 March 2010). The fresh weight (FW) and dry weight (DW) of plants were recorded at each harvest and the number of flowers was counted at the end of the experimental period.

$\mathrm{CO}_{2}$ assimilation was measured on three plants of the cultivar 'Blue Get Mee' grown in LD on the 18 October 2009, using a portable open infrared gas-exchange system (CIRAS-2, PP-systems, Hitchin, United Kingdom). A fully matured leaf was clamped into a leaf cuvette $\left(2.5 \mathrm{~cm}^{2}\right)$ with light, humidity and temperature control. A light response curves was developed within the range of $0-1600 \mu \mathrm{mol} \mathrm{m}^{-2} \mathrm{~s}^{-1}$. The $\mathrm{CO}_{2}$ concentration was $600 \mu \mathrm{ll}^{-1}$ and the temperature was $18^{\circ} \mathrm{C}$.

\subsection{Calculation of electricity costs}

The electricity cost to deliver $60 \mu \mathrm{mol} \mathrm{m}^{-2}$ at table level by the four high-pressure sodium lamps (SON-T agro) placed in each treatment was estimated to $90 \mathrm{~W} \mathrm{~m}^{-2}$. Based on this installation the cost of electricity was calculated in relation to the price on electricity during the exact hours the supplemental light was turned on in the different treatments. The calculations were carried out using a software package (DynaLight Web; University of Southern Denmark, Odense, Denmark). The climate data from the greenhouse climate computer was uploaded to DynaLight Web and calculations of electricity use in $\mathrm{kWh} \mathrm{m}^{-2}$, and price of electricity in euro $\left(€ / \mathrm{m}^{2}\right)$ were based on the climate data and hourly changes in electricity prices obtained from NordPool (Nord Pool Spot, 2011). Calculations of DPI $\left(\mathrm{mmol} \mathrm{CO}_{2} \mathrm{~m}^{-2}\right.$ leaf) were based on the climate data and the leaf photosynthesis model described by Aaslyng et al. (2003).

\subsection{Statistical analysis}

Statistical analyses were carried out using the R-language 'stat' package, release 2.12.0 (R Foundation for Statistical Computing, 2010). Climatic data was extracted from the environmental climate computer and values of means, max, min, sum and standard errors of PPF and hours of light were calculated in relation to treatment using the 'SummaryBy' work package (doBy). The effect of time and treatment on total means of climatic parameters and harvest data of plant DW and number of flowers were analysed by a generalised 


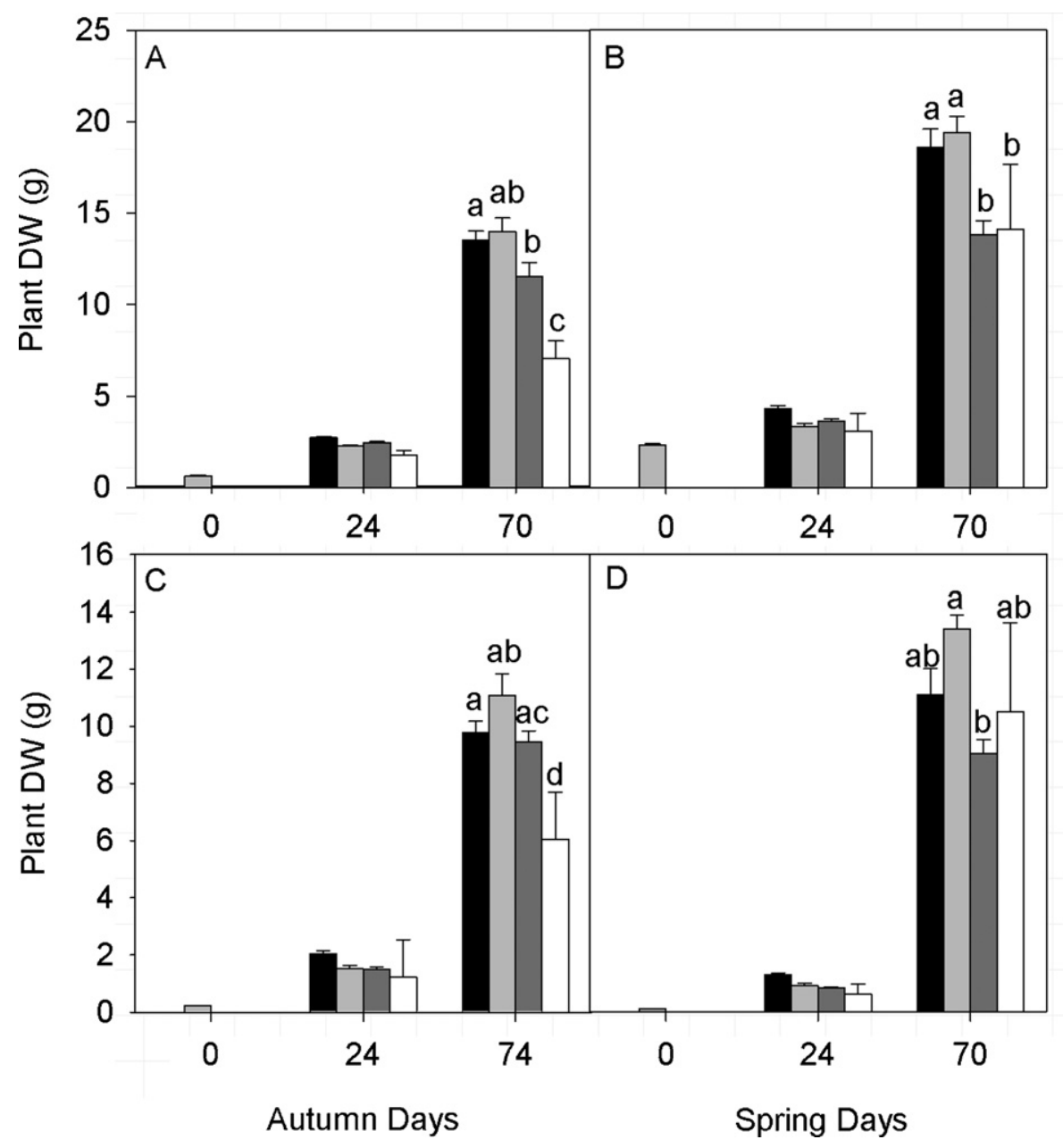

Fig. 3. Plant dry weight (DW) of campanula plants grown in four greenhouse treatments with different light control strategies. Treatments were long day (LD) with a day length of $\approx 19 \mathrm{~h}$ (black bars), $600 \mathrm{NB}$ with a set point for daily photosynthesis integral (DPI) of $600 \mathrm{mmol} \mathrm{CO}_{2} \mathrm{~m}^{-2}$ leaf s $\mathrm{s}^{-1}$ (light grey bars), $450 \mathrm{NB}^{*}$ with DPI $\approx 450 \mathrm{mmol} \mathrm{CO} 2$ $\mathrm{m}^{-2}$ leaf s $\mathrm{s}^{-1}$ (dark grey bars) and $300 \mathrm{NB}$ with $\mathrm{DPI} \approx 300 \mathrm{mmol} \mathrm{CO} \mathrm{m}^{-2}$ leaf $\mathrm{s}^{-1}$ (white bars). NB refers to irregular night breaks of light. Plant DW of Campanula cultivar 'Blue Wonder' in autumn (A), and spring (B). Plant DW of Campanula cultivar 'Blue Get Mee' in autumn (C), and spring (D). Values are mean values of six plants ( \pm SE) for each harvest. Different letters indicate significant difference in probability values between treatments $(P<0.05)$.

linear model allowing for nested random effects (GLM-function). Means of the different treatments were separated by a pairwise $t$-test using the Holm correction (95\% confidence intervals).

\section{Results}

\subsection{Climate}

The DLI decreased from $5.1 \pm 0.3$ to $1.9 \pm 0.1 \mu \mathrm{mol} \mathrm{m}^{-2} \mathrm{~d}^{-1}$ during the autumn experiment and increased from $1.5 \pm 0.3$ to
$5.7 \pm 0.4 \mu \mathrm{mol} \mathrm{m}^{-2} \mathrm{~d}^{-1}$ during the spring experiment (Fig. 2a and b). This was expected due to the decrease/increase in natural day length and solar irradiance during the two periods and this associated, resulted in a larger contribution of supplemental light to DLI in the autumn experiment in comparison to the spring experiment (Table 1). This also resulted in longer periods of NB lighting during the last five weeks in autumn compared to the same period in spring (Fig. 2d and e).

The $24 \mathrm{~h}$ duration of light periods varied between subsequent days in both the $300 \mathrm{NB}$ and $600 \mathrm{NB}$ treatments (results not shown).

Table 1

Climatic parameters in four greenhouse treatments with different light control strategies. ${ }^{\mathrm{A}}$ Values of daily light integral(DLI), daily light duration (DLD) and DLI of supplemental light (SL) are the average of all daily values for each treatment ( \pm SE).

\begin{tabular}{|c|c|c|c|c|}
\hline Experiment & Treatment & $\operatorname{DLI}\left(\mathrm{mol} \mathrm{m}^{-2} \mathrm{~d}^{-1}\right)$ & $\operatorname{DLD}\left(\mathrm{hd}^{-1}\right)$ & SL (\% DLI) \\
\hline \multirow[t]{4}{*}{ Autumn } & LD & $3.0 \pm 0.2 a^{B}$ & $18.4 \pm 0.1 \mathrm{a}$ & $67.6 \pm 3.0 \mathrm{a}$ \\
\hline & $600 \mathrm{NB}$ & $2.6 \pm 0.2 \mathrm{~b}$ & $18.4 \pm 0.3 \mathrm{a}$ & $62.0 \pm 3.4 \mathrm{a}$ \\
\hline & $450 \mathrm{NB}^{*}$ & $2.1 \pm 0.2 \mathrm{~b}$ & $14.9 \pm 0.3 b$ & $54.3 \pm 3.6 b$ \\
\hline & $300 \mathrm{NB}$ & $1.7 \pm 0.2 c$ & $11.3 \pm 0.3 c$ & $41.2 \pm 3.9 c$ \\
\hline \multirow[t]{4}{*}{ Spring } & LD & $4.4 \pm 0.3 \mathrm{a}$ & $19.3 \pm 0.1 \mathrm{a}$ & $32.6 \pm 2.3 \mathrm{a}$ \\
\hline & $600 \mathrm{NB}$ & $4.0 \pm 0.2 \mathrm{ab}$ & $16.5 \pm 0.4 b$ & $25.8 \pm 2.5 \mathrm{~b}$ \\
\hline & $450 \mathrm{NB}^{*}$ & $3.6 \pm 0.2 \mathrm{ab}$ & $13.3 \pm 0.3 c$ & $17.5 \pm 2.4 \mathrm{c}$ \\
\hline & $300 \mathrm{NB}$ & $3.3 \pm 0.2 \mathrm{~b}$ & $10.3 \pm 0.2 \mathrm{~d}$ & $4.5 \pm 1.0 \mathrm{~d}$ \\
\hline
\end{tabular}

A Treatments were long day (LD) with a day length of $\approx 19 \mathrm{~h}, 600 \mathrm{NB}$ with a set point for daily photosynthesis integral (DPI) of $600 \mathrm{mmol}^{\mathrm{CO}} \mathrm{m}_{2} \mathrm{~m}^{-2}$ leaf $\mathrm{s}^{-1}, 450 \mathrm{NB}^{*}$ $\left(\mathrm{DPI} \approx 450 \mathrm{mmol} \mathrm{CO}_{2} \mathrm{~m}^{-2}\right.$ leaf s $\left.\mathrm{s}^{-1}\right)$ and including $\approx 19 \mathrm{~h}$ incandescent light $\left(<5 \mu \mathrm{mol} \mathrm{m}^{-2} \mathrm{~s}^{-1}\right)$, and $300 \mathrm{NB}\left(\mathrm{DPI} \approx 300 \mathrm{mmol} \mathrm{CO} 2 \mathrm{~m}^{-2}\right.$ leaf s $\left.\mathrm{s}^{-1}\right)$. NB refers to irregular night breaks of light.

B Different letters indicate significant difference in probability values between treatments within each experiment $(P<0.05)$. 


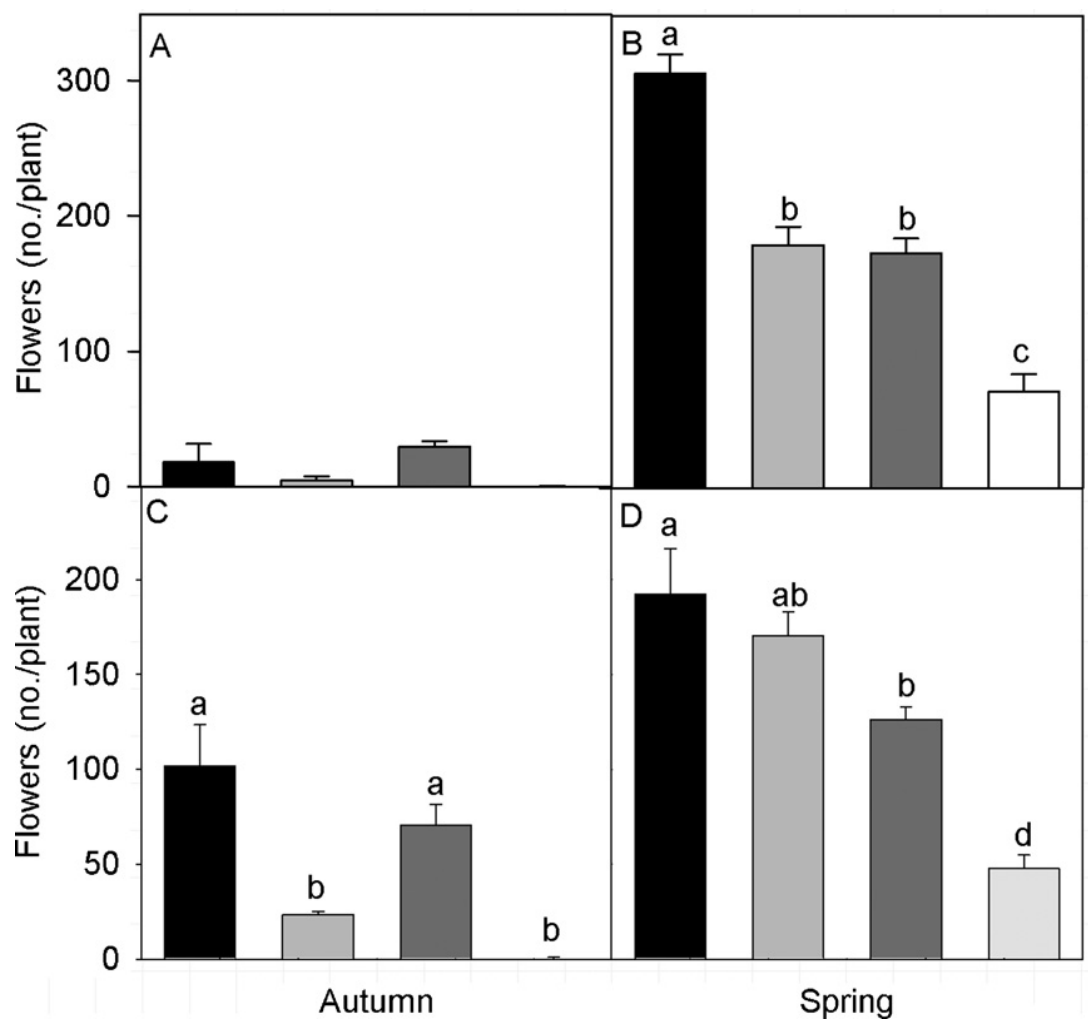

Fig. 4. The average number of flowers per plant at the final harvest. Campanula plants were grown in four greenhouse treatments with different light control strategies. Treatments were long day (LD) with a day length of $\approx 19 \mathrm{~h}$ (black bars), $600 \mathrm{NB}$ with a set point for daily photosynthesis integral (DPI) of $600 \mathrm{mmol} \mathrm{CO}_{2} \mathrm{~m}^{-2}$ leaf $\mathrm{s}^{-1}$ (light grey bars), $450 \mathrm{NB}^{*}$ with $\mathrm{DPI} \approx 450 \mathrm{mmol} \mathrm{CO}_{2} \mathrm{~m}^{-2}$ leaf s $\mathrm{s}^{-1}$ (dark grey bars) and $300 \mathrm{NB}$ with $\mathrm{DPI} \approx 300 \mathrm{mmol} \mathrm{CO}_{2} \mathrm{~m}^{-2}$ leaf s $^{-1}$ (white bars). Number of flowers on Campanula cultivar 'Blue Wonder' in autumn (A), and in spring (B). Number of flowers on Campanula cultivar 'Blue Get Mee' in autumn (C), and spring (D). Values are mean values of six plants $( \pm$ SE). Different letters indicate significant difference in probability values between treatments $(P<0.05)$.

The average DLD per week was constant in the 300 NB treatment, however the average DLD per week increased during autumn and decreased during spring in the $600 \mathrm{NB}$ treatment and for the periods of supplemental light in the $450 \mathrm{NB}^{*}$ treatment. This illustrated that the solar irradiation was a limiting factor for obtaining the set point of DPI in these two treatments $\left(600\right.$ and $450 \mathrm{mmol} \mathrm{CO}_{2} \mathrm{~m}^{-2}$ leaf $\mathrm{d}^{-1}$ ) by the end of the autumn experiment and in the beginning of the spring experiment compared to the $300 \mathrm{NB}$ treatment (Fig. 2a and $\mathrm{b}$ ). For the LD and the $450 \mathrm{NB}^{*}$ treatment (when incandescent light was included) the average DLD was constant throughout the experimental period in both autumn and spring and above $18 \mathrm{~h}$ (Fig. 2c and d).

The light intensities were relatively low in both experimental periods resulting in an average DLI of $2.4 \pm 0.1 \mu \mathrm{mol} \mathrm{m}^{-2} \mathrm{~d}^{-1}$ in autumn, and $3.7 \pm 0.1 \mu \mathrm{mol} \mathrm{m}^{-2} \mathrm{~d}^{-1}$ in spring. This induced only minor differences in daily means of $\mathrm{CO}_{2}$, temperature and $\mathrm{RH}$ between the treatments. The average values per day across treatments were $695 \pm 2.8 \mu \mathrm{Il}^{-1} \mathrm{CO}_{2}, 18 \pm 0.03^{\circ} \mathrm{C}$ and $68 \pm 0.4 \% \mathrm{RH}$ in the autumn experiment and $650 \pm 5.7 \mu \mathrm{Il}^{-1} \mathrm{CO}_{2}, 18 \pm 0.1^{\circ} \mathrm{C}$ and $48 \pm 1 \% \mathrm{RH}$ in the spring experiment.

\subsection{Plant growth and flowering}

The cultivars showed similar trends in plant DW in response to the different treatments in both experimental periods (Fig. 3), but both cultivars accumulated more dry matter during the 10 week period in spring compared to autumn. Plants grown in 600 NB appeared larger than the plants grown in $L D$, but there was no significant difference in plant DW between these two treatments. Plants grown in the 300 NB were significantly smaller than

Table 2

Daily photosynthesis integral (DPI) and cost of electricity for supplemental light in four greenhouse treatments with different light control strategies. ${ }^{\text {a }}$

\begin{tabular}{|c|c|c|c|c|c|}
\hline Experiment & Treatment & $\begin{array}{l}\text { DPI }\left(\mathrm{mmol} \mathrm{m}^{-2}\right. \\
\text { leaf })\end{array}$ & $\begin{array}{l}\text { Electricity use } \\
\left(\mathrm{kWh} / \mathrm{m}^{2}\right)\end{array}$ & $\begin{array}{l}\text { Cost of electricity } \\
\left(€ / \mathrm{m}^{2}\right)\end{array}$ & $\begin{array}{l}\text { Relative use/cost (\% } \\
\text { max) }\end{array}$ \\
\hline \multirow[t]{4}{*}{ Autumn } & LD & 669 & 100.5 & 6.31 & $100 / 100$ \\
\hline & $600 \mathrm{NB}$ & 522 & 71.7 & 4.37 & $71 / 69$ \\
\hline & $450 \mathrm{NB}^{*}$ & 413 & 47.0 & 2.75 & $47 / 44$ \\
\hline & $300 \mathrm{NB}$ & 264 & 23.0 & 1.29 & $23 / 21$ \\
\hline \multirow[t]{4}{*}{ Spring } & LD & 782 & 44.9 & 2.64 & $100 / 100$ \\
\hline & $600 \mathrm{NB}$ & 662 & 33.5 & 1.95 & $75 / 74$ \\
\hline & $450 \mathrm{NB}^{*}$ & 519 & 15.5 & 0.85 & $34 / 32$ \\
\hline & $300 \mathrm{NB}$ & 387 & 2.9 & 0.16 & $7 / 6$ \\
\hline
\end{tabular}

DPI was estimated from the photosynthesis model. DPI is the mean and electricity use and cost of electricity are the sum for three months in autumn 2009 (10 October-17 December) and two months in spring 2010 (29 January-24 March) and calculated on the basis of the price of electricity during the relevant hours the supplemental light was turned on (DynaLight Web, 2011).

a Treatments were long day (LD) with a day length of $\approx 19 \mathrm{~h}, 600 \mathrm{NB}$ with a set point for daily photosynthesis integral (DPI) of $600 \mathrm{mmol} \mathrm{CO}_{2} \mathrm{~m}^{-2}$ leaf $\mathrm{s}^{-1}$, $450 \mathrm{NB}^{*}$ $\left(\mathrm{DPI} \approx 450 \mathrm{mmol} \mathrm{CO}_{2} \mathrm{~m}^{-2}\right.$ leaf s $\left.\mathrm{s}^{-1}\right)$ and including $\approx 19 \mathrm{~h}$ incandescent light $\left(<5 \mu \mathrm{mol} \mathrm{m}^{-2} \mathrm{~s}^{-1}\right)$, and $300 \mathrm{NB}\left(\mathrm{DPI} \approx 300 \mathrm{mmol} \mathrm{CO} 2 \mathrm{~m}^{-2}\right.$ leaf $\left.\mathrm{s}^{-1}\right)$. NB refers to irregular night breaks of light. 


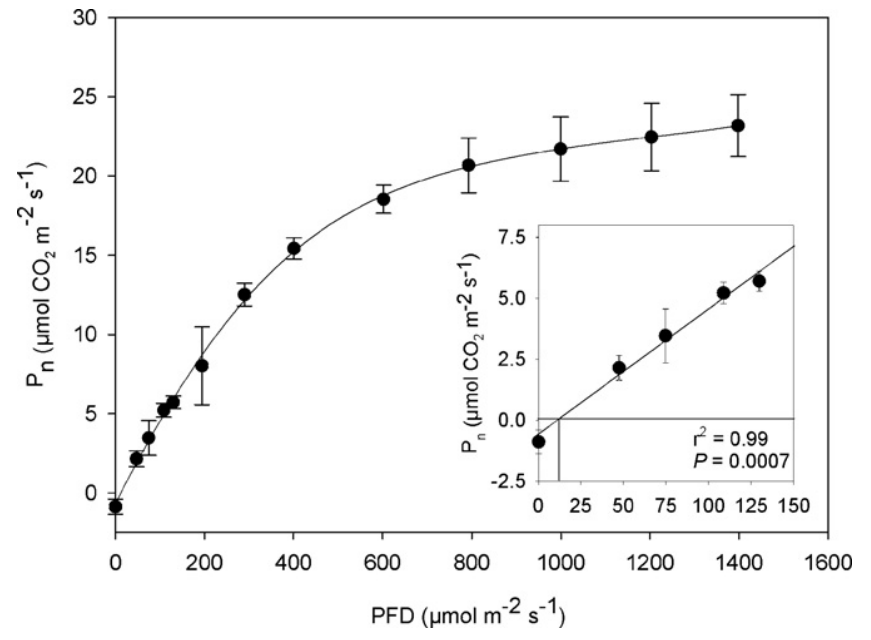

Fig. 5. Light response curve showing the relationship between $\mathrm{CO}_{2}$ assimilation $\left(\mu \mathrm{mol} \mathrm{CO} \mathrm{C}^{-2} \mathrm{~s}^{-1}\right.$ ) in Campanula portenschlagiana 'Blue Get Mee' and photosynthetic active radiation (PAR, $\mu \mathrm{mol} \mathrm{m}^{-2} \mathrm{~s}^{-1}$ ). Values are mean values of three plants $( \pm \mathrm{SE})$.

plants grown in all other treatments in the autumn, but were similar in size to plants grown in the $450 \mathrm{NB}^{*}$ treatment during spring. The significant decrease in plant DW when grown in 300 NB was due to a significantly lower DLI and shorter DLD in this treatment (Table 1). However, differences in DLI and DLD between treatments could not explain the slight increase in plant DW in $600 \mathrm{NB}$ or the similarities in plant DW between $450 \mathrm{NB}^{*}$ and the three other treatments. However, for the $450 \mathrm{NB}^{*}$ treatment the continuous lighting with incandescent lamps may have decreased respiration, as $5 \mu \mathrm{mol} \mathrm{m}{ }^{-2} \mathrm{~s}^{-1}$ was below the light compensation point for net $\mathrm{CO}_{2}$ assimilation in the cultivar 'Blue Get Mee' grown under LD conditions (Fig. 5).

Plants grown in the 300 NB treatment during autumn had less than three open flowers per plant at the time of harvest, and over $50 \%$ of the plants had no open flowers (Fig. $4 \mathrm{a}$ and c). For plants grown in the $600 \mathrm{NB}$ treatment, $100 \%$ of the plants of both cultivars flowered, but $50 \%$ of 'Blue Wonder' had less than 3 open flowers and 50\% of 'Blue Get Mee' had less than 30 open flowers. In contrast, flowering was more pronounced in the $450 \mathrm{NB}^{*}$ and in the LD treatment, but the variation in flower number between individual plants was relatively high. The results illustrated that a continuous long light period (LD), whether achieved by supplemental light $\left(60 \mu \mathrm{mol} \mathrm{m}^{-2} \mathrm{~s}^{-1}\right)$ or by incandescent light $\left(<5 \mu \mathrm{mol} \mathrm{m}^{-2} \mathrm{~s}^{-1}\right)$ was important for maintaining the reproductive development of campanula plants grown with decreasing DLI. In contrast, the number of open flowers was relatively high and uniform for plants grown in all four treatments during spring. Furthermore, the number of flowers was not significantly decreased by NB-lighting or shorter days in the 600 $\mathrm{NB}$ treatment compared to the $450 \mathrm{NB}^{*}$ treatment. This indicated that campanula plants were less dependent on a continuous long light period when light intensity was higher and DLI was increasing (Fig. 4b and c). The average maximum light intensity measured per day in spring was $411.3 \pm 28.6 \mu \mathrm{mol} \mathrm{m}^{-2} \mathrm{~s}^{-1}$ in contrast to $210.8 \pm 20.6 \mu \mathrm{mol} \mathrm{m}^{-2} \mathrm{~s}^{-1}$ measured in autumn.

\subsection{Electricity costs}

The relative savings in electricity costs in the three DynaLight strategies in comparison to the traditional LD treatment were similar in the two experiments (Table 2), but the use of electricity was more than $50 \%$ higher in autumn than in spring due to increased use of supplemental light. In spring, 25\% savings were achieved on both electricity use and electricity cost in the 600 NB treatment compared to LD. In contrast the DPI was only reduced by $20 \%$ in this treatment. When decreasing the electricity use in both autumn and spring, the cost was always further decreased illustrating a beneficial effect of using the supplemental light in low-cost periods.

\section{Discussion}

It is evident that large savings in electricity costs can be achieved by growing campanula species under supplemental light control strategies based on forecasted solar irradiance and electricity prices regulated by predefined DPI's. The flowering percentage was uniform in all treatments in spring conditions and differences in the number of flowers per plant were mainly related to differences in DLI as also seen in other plants, for example Salvia splendens, Tagets patula and Cyclamen persicon (Moccaldi and Runkle, 2007; Oh et al., 2009). That the irregular light conditions only marginally affected the reproductive development of the plants grown in spring was shown in a similar or even higher number of flowers per plant in the $600 \mathrm{NB}$ compared to $450 \mathrm{NB}^{*}$. Furthermore, the quality of the plants grown in $600 \mathrm{NB}$ was commercially acceptable, and achieved with a $25 \%$ reduction in the cost of electricity compared to LD conditions.

The uniform flowering of campanulas in all treatments during spring illustrated that it was possible to maintain flower induction and retain the campanula plants in a reproductive stage during production when the use of supplemental light occurred in a very irregular pattern. However, this was only possible when the DLI was increasing. When DLI was decreasing a high level of variation in the amount of flowers per plant was seen for both species in all treatments in the autumn experiment (Fig. 4). However, LD conditions or conditions where continuous low cost incandescent light was applied during the night triggered the plants to flower, possibly through the effects of the phytochrome system (Moe et al., 1991; Runkle et al., 1998; King et al., 2008; Blanchard and Runkle, 2010). In Arabidopsis LD plants, expression of the FLOWERING LOCUS T(FT) and flowering was promoted by both low-intensity incandescent lamps with a high amount of far-red (FR) light and high intensity red (R) light (King et al., 2008). This illustrated that plants may use both primary controlling factors such as day length and secondary controlling factors such as light intensity and light quality to control flowering in different environments (Bernier and Perilleux, 2005).

From the present results, we suggest that the phytochrome response to FR-light played a critical role in flowering of campanula under the low light conditions, whereas the FR-light response and LD conditions were less important under high light intensities and increasing DLI. High light intensities have further been shown to promote long-distance signalling by sucrose supplied through the photosynthetic input, which is crucial for flowering time control in Arabidopsis (Bernier and Perilleux, 2005).

In vegetative chrysanthemums, dry matter accumulation appeared linearly related to the cumulative light integral irrespective of irregular light conditions (Kjaer and Ottosen, 2011). This was not seen in the present study, as plants were similar in size irrespective of differences in DLI between the LD and the $600 \mathrm{NB}$ treatments. This indicated that there was an interaction between the reproductive development of the plants and $\mathrm{CO}_{2}$ assimilation or dry matter allocation to other plant parts when grown under irregular light conditions. Furthermore, differences in leaf anatomy and physiology of the photosynthetic apparatus may have changed the photosynthetic area and light use efficiency of the plants as reported for chrysanthemums grown under irregular light (Kjaer 
and Ottosen, 2011), and for plants grown under LD conditions in comparison to SD conditions (Adams and Langton, 2005).

\section{Conclusion}

Our results demonstrate that it is possible to grow different species of the LD plant campanula in a climate where the light period is split into a natural light period plus irregular NB lighting. Low natural light intensities during autumn caused non-uniform flowering, and irregular light conditions further impaired the development of flowers. However, this effect was reduced by the use of continuous lighting with incandescent lamps. Under conditions with increasing DLI and higher light intensities, flowering occurred uniformly even though DLD decreased due to a reduced use of supplemental light. These results illustrate that increasing DLI and light intensity are more important for flowering of campanula than the actual day length.

\section{Acknowledgements}

This work was supported by the Ministry of Food, Agriculture and Fisheries, Denmark. We thank Ruth Nielsen and Helle Sørensen for excellent support in the propagation and maintenance of the plants and technical assistance.

\section{References}

Aaslyng, J.M., Lund, J.B., Ehler, N., Rosenqvist, E., 2003. IntelliGrow: a greenhouse component-based climate control system. Environmental Modelling \& Software 18, 657-666.

Adams, S.R., Langton, F.A., 2005. Photoperiod and plant growth: a review. Journal of Horticultural Sciences and Biotechnology 80, 2-10.

Albrecht, M.L., Lehmann, J.T., 1991. Day length, cold-storage, and plant-production method influence growth and flowering of Asclepias tuberosa. HortScience 26, 120-121.

Bernier, G., Perilleux, C., 2005. A physiological overview of the genetics of flowering time control. Plant Biotechnology Journal 3, 3-16.
Bickford, E.D., Dunn, S., 1972. Lighting for Plant Growth. Kent State Univ. Press, Kent, Ohio.

Blanchard, M.G., Runkle, E.S., 2010. Intermittent light from a rotating highpressure sodium lamp promotes flowering of long-day plants. HortScience 45 236-241.

Dodd, A.N., Salathia, N., Hall, A., Kevei, E., Toth, R., Nagy, F., Hibberd, J.M., Millar, A.J., Webb, A.A.R., 2005. Plant circadian clocks increase photosynthesis, growth, survival, and competitive advantage. Science 309, 630-633.

Danish Meterological Institute, 2011. 17 February 2011. http://www.dmi. $\mathrm{dk} / \mathrm{dmi} /$ index/.

DynaLight Web. 2011. 17 February 2011. http://softwarelab.sdu.dk/DynaLight/.

Hamaker, C.K., Heins, R., Cameron, A., Carlson, W., 1996. Perennials: Best long-day treatments for your varieties. GrowerTalks 60, 36-42.

King, R.W., Hisamatsu, T., Goldschmidt, E.E., Blundell, C., 2008. The nature of floral signals in Arabidopsis. I. Photosynthesis and a far-red photoresponse independently regulate flowering by increasing expression of FLOWERING LOCUS T (FT). Journal of Experimental Botany 59, 3811-3820.

Kjaer, K.H., Ottosen, C.-O., 2011. Growth of Chrysanthemum in response to supplemental light provided by irregular light breaks during the night. Journal of the American Society of Horticultural Science 136, 3-9.

Markvart, J., Rosenqvist, E., Sorensen, H., Ottosen, C.-O., Aaslyng, J.M., 2009. Canopy photosynthesis and time-of-day application of supplemental light. HortScience $44,1284-1290$

Moccaldi, L.A., Runkle, E.S., 2007. Modelling the effects of temperature and photosynthetic daily light integral on growth and flowering of Salvia splendens and Tagetes patula. Journal of the American Society of Horticultural Sciences 132, 283-288.

Moe, R., Heide, O.M., 1985. Campanula isophylla. In: Haley, A.H. (Ed.), Handbook of Flowering, vol. II. CRC Press, Boca Raton, FL, pp. 119-122.

Moe, R., Heins, R.D., Erwin, J., 1991. Stem elongation and flowering of the long-day plant Campanula isophylla 'Moretti' in response to day and night temperature alternations and light quality. Scientia Horticulturae 48, 141-151.

Nord Pool Spot, 2011. System price. 17 February 2010. http://www.nordpoolspot.com/reports/systemprice/.

Oh, W., Cheon, I.H., Kim, K.S., Runkle, E.S., 2009. Photosynthetic daily light integral influences flowering time and crop characteristics of Cyclamen persicon. HortScience 44, 341-344.

R Foundation for Statistical Computing, 2010. The comprehensive R archive network. 17 December. http://mirrors.dotsrc.org/cran/.

Resco, V., Hartwell, J., Hall, A., 2009. Ecological implications of plants' ability to tell the time. Ecology Letters 12, 583-592.

Runkle, E.S., Heins, R.D., Cameron, A.C., Carlson, W.H., 1998. Flowering of herbaceous perennials under various night interruption and cyclic lighting treatments. HortScience 33, 672-677. 